\title{
A Sequential Double-Label Autoradiographic Method that Quantifies Altered Rates of Regional Glucose Metabolism
}

\author{
JAMES L. OLDS, KIRK A. FREY, R.L. EHRENKAUFER and B.W. AGRANOFF \\ Neuroscience Laboratory and Cyclotron/PET Facility, University of Michigan, Ann Arbor, MI 48109 (U.S.A.)
}

(Accepted April 16th, 1985)

Key words: brain metabolism - fluorodeoxyglucose - ibotenic acid — barbiturate anesthesia

\begin{abstract}
An autoradiographic sequential double-label variant of the deoxyglucose method for measurement of local glucose utilization has been developed. This technique takes advantage of the short half-life of the positron emitter, ${ }^{18 \mathrm{~F}}\left(\mathrm{t}_{1 / 2}=110\right.$ min) relative to that of ${ }^{14} \mathrm{C}$. Sequential injection of $\left[{ }^{18} \mathrm{~F}\right]$ fluorodeoxyglucose (FDG) and ${ }^{14} \mathrm{C}$-labeled FDG allows the production of two separable autoradiograms, each of which represents the same $20-\mu \mathrm{m}$ brain slice, but under potentially different cerebral metabolic states. We have used this technique to demonstrate that ibotenic acid-lesioned rat striatum is selectively refractory to the depressing effects of barbiturate anesthesia upon brain glucose utilization. The described method has applicability to the analysis of small changes in regional cerebral metabolism in localized brain regions and represents a solution to the problem of intersubject variability inherent in conventional approaches to the deoxyglucose method.
\end{abstract}

\section{INTRODUCTION}

The usefulness of the $\left[{ }^{14} \mathrm{C}\right] 2$-deoxyglucose (2-DG) method for autoradiographic determination of the local cerebral metabolic rate of glucose (LCMRglc) in evaluating regional functional neuronal activity under a wide variety of physiological and behavioral conditions is well documented6,27,28. A limitation of the technique lies in the intrinsic metabolic variability between subjects unrelated to the experimental manipulations ${ }^{1}$. Thus, detection of small but significant alterations in regional glucose utilization that might be anticipated as a result of subtle physiological or behavioral changes requires the use of large numbers of animals, adding to the time and expense of experiments.

A solution to this problem is to utilize each subject as its own control, by employing two isotopically labeled forms of deoxyglucose administered sequentially during resting and stimulated states. Previous work from this laboratory using brain tissue punches from rats undergoing vibrissal stimulation ${ }^{4}$ demonstrates the feasibility of this technique. The punch technique has the drawback, however, that anatomical resolution is poor compared with autoradiographic methods.

Following the installation of a medical cyclotron for positron emission tomography (PET), the positron emitter ${ }^{18} \mathrm{~F}$ became available locally and thus provided the opportunity to design a new sequential double-label protocol based on autoradiography ${ }^{24}$. Isotopic separation is based on the short half-life of $18 \mathrm{~F}\left(\mathrm{t}_{1 / 2}=110 \mathrm{~min}\right)$, the design of a radiochemical synthesis of $\left.{ }^{18} \mathrm{~F}\right]$ fluorodeoxyglucose (FDG) ${ }^{10}$ and the commercial availability of $\left[{ }^{14} \mathrm{C}\right] \mathrm{FDG}$. Double-label autoradiography employing ${ }^{18} \mathrm{~F}$ and ${ }^{14} \mathrm{C}$ has been previously employed in studies of local cerebral blood flow (LCBF) and LCMRglc in the same animal using $\left[{ }^{14} \mathrm{C}\right]$ iodoantipyrine and $\left[{ }^{18} \mathrm{~F}\right] \mathrm{FDG}$, respectively ${ }^{26}$. In addition, other $\gamma$ radiation- or positron-emitting radionuclides such as ${ }^{11} \mathrm{C},{ }^{123} \mathrm{I},{ }^{131} \mathrm{I},{ }^{99} \mathrm{~m} \mathrm{Tc}$ and ${ }^{68} \mathrm{Ga}$ have been used in various combinations to produce multiple images for clinical applications ${ }^{7,9,14-16,18}$.

In the present study the two isotopic forms of FDG, injected sequentially, are shown to lead to two separable autoradiograms, each of which represents

Correspondence: B.W. Agranoff, Neuroscience Lab Building, University of Michigan, 1103 East Huron, Ann Arbor, MI 48109, U.S.A. 
a different physiological state in the same tissue slice.

\section{MATERIALS AND METHODS}

$\left[{ }^{14} \mathrm{C}\right] \mathrm{FDC}$ was either purchased from New England Nuclear (Boston, MA), or was the generous gift of Dr. Surenvra Gupta, American Radiolabeled Chemical (St. Louis, MO). Specific activities were $343.0 \mathrm{mCi} / \mathrm{mmol}$ and $325 \mathrm{mCi} / \mathrm{mmol}$, respectively. ${ }^{18} \mathrm{~F}$-Labeled FDG was obtained from the University of Michigan Cyclotron/PET Facility using a previously described synthesis ${ }^{10}$. Ibotenic acid was purchased from Regis Chemical (Morton Grove, IL). Male Sprague-Dawley rats weighing between 180 and 200 $\mathrm{g}$ were obtained from Harlan Sprague-Dawley (Indianapolis, IN).

\section{Calibration of ${ }^{14} \mathrm{C}$ plastic standards for quantitation of ${ }^{18} \mathrm{~F}$}

Autoradiographic standardization was performed using a modification of previously described methods 22.28 . Rat brain tissue paste was mixed with varying amounts of $\left[{ }^{18} \mathrm{~F}\right] \mathrm{FDG}$, frozen, sliced in $20-\mu \mathrm{m}$ sections on a cryostat and exposed to Kodak SB-5 X-ray film for $12 \mathrm{~h}$ along with a set of ${ }^{14} \mathrm{C}$ plastic standards. Optical densities of the resultant autoradiograms determined with a computer-assisted spot densitometer ${ }^{8}$ were plotted against tissue ${ }^{18} \mathrm{~F}$ content.

\section{Animal preparation}

In initial validation studies, rats were catheterized in both the femoral artery and vein under light diethyl ether anesthesia and allowed to recover for 4 $\mathrm{h}^{28}$. To initiate the experiments, they were injected simultaneously with $100 \mu \mathrm{Ci} / \mathrm{kg}$ of $\left[{ }^{14} \mathrm{C}\right] \mathrm{FDG}$ and 25 $\mathrm{mCi} / \mathrm{kg}$ of $[18 \mathrm{~F}] \mathrm{FDG}$. Arterial plasma was sampled for ${ }^{14} \mathrm{C},{ }^{18 \mathrm{~F}}$ and glucose during the incorporation period. After $45 \mathrm{~min}$ the animals were killed, brains were rapidly dissected, then frozen and sectioned into $20-\mu \mathrm{m}$ slices, which were rapidly dried 28 .

\section{Exposure of autoradiograms}

A 12-h autoradiographic exposure on Kodak SB-5 $X$-ray film, which reflected primarily $\left[{ }^{18} \mathrm{~F}\right] \mathrm{FDG}$ uptake, was initiated $4 \mathrm{~h}$ after FDG injection. Three days later (about $40^{18} \mathrm{~F}$ half-lives), a 7 -day film exposure for ${ }^{14} \mathrm{C}$ was initiated. Isotope concentrations were determined from the resulting autoradiograms using computer-assisted densitometry averaged over adjacent sections. The first image thus reflected primarily ${ }^{18} \mathrm{~F}$ decay while the second image reflected only ${ }^{14} \mathrm{C}$ decay. In some experiments, a $50-\mu \mathrm{m}$-thick sheet of aluminum foil was interposed between the tissue and the X-ray film to minimize the contribution of ${ }^{14} \mathrm{C}$ to the ${ }^{18} \mathrm{~F}$ autoradiogram, as discussed in Results.

\section{Ibotenic acid lesions}

Striatal lesions were made according to the method of Frey and Agranoff 11 . Briefly, $20 \mu \mathrm{g}$ of sodium ibotenate was injected into the right striatum. After 7 days the rats were injected intravenously with $\left[{ }^{14} \mathrm{C}\right] \mathrm{FDG}$ and $30 \mathrm{~min}$ later they were injected with pentobarbital ( $2 \mathrm{mg} / \mathrm{kg}$, i.v.) followed by $\left[{ }^{18} \mathrm{~F}\right] \mathrm{FDG}$. Animals were killed after the second 30-min incorporation pulse, brains were removed and sectioned and both immediate and delayed autoradiograms were made as described above.
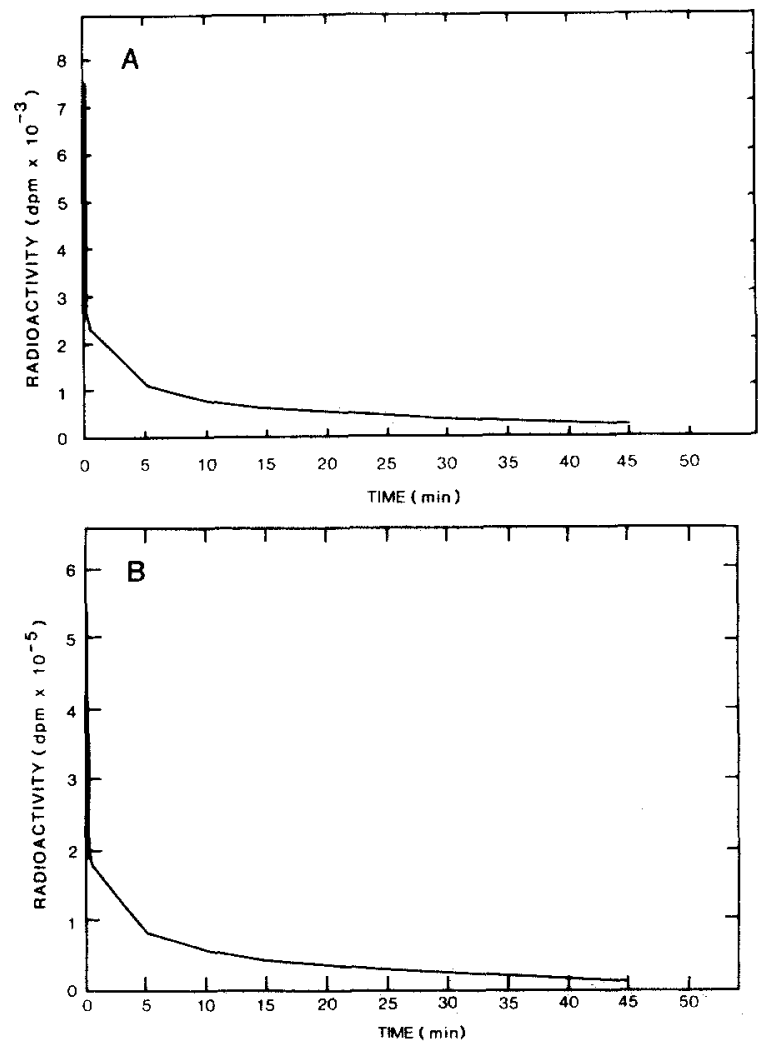

Fig. 1. Plasma input functions for an animal injected simultaneously with both isotopically labeled forms of FDG. A: $\left[{ }^{14} \mathrm{C}\right] \mathrm{FDG}, \mathrm{B}:\left[{ }^{18} \mathrm{~F}\right] \mathrm{FDG}$. 
TABLE I

Summary of LCMRglc data from a rat injected simultaneously with $\left[{ }^{18} F\right] F D G$ and $\left[{ }^{14} C J F D G\right.$

Glucose utilization units are $\mu \mathrm{mol} / 100 \mathrm{~g}$ tissue $/ \mathrm{min} \pm \mathrm{S} . \mathrm{D} . ; \mathrm{n}=12$.

\begin{tabular}{llll}
\hline Region & $\int^{18}$ FJLCMRglc & ${ }^{14}$ C]LCMRglc & Ratio \\
\hline Caudate putamen & $118.82 \pm 1.76$ & $68.70 \pm 5.26$ & 1.73 \\
Motor cortex & $119.83 \pm 1.35$ & $73.70 \pm 6.89$ & 1.63 \\
Somatosensory cortex & $124.08 \pm 4.18$ & $75.68 \pm 7.06$ & 1.64 \\
Substantia nigra & $87.67 \pm 2.94$ & $33.78 \pm 2.12$ & 2.60 \\
Globus pallidus & $79.94 \pm 4.94$ & $32.51 \pm 1.14$ & 2.46 \\
\hline
\end{tabular}

\section{RESULTS}

The plasma curves for ${ }^{18} \mathrm{~F}$ and ${ }^{14} \mathrm{C}$ radioactivity (Fig. 1) appear to be similar. Regional glucose utilizations from a simultaneous injection experiment (Table I) showed that the LCMRglc (18F)/LCMRglc $\left({ }^{14} \mathrm{C}\right)$ ratio was not unity, and in fact appeared to vary systematically in 5 selected brain regions: it was greater for regions with lower relative FDG uptake. The same trend was seen in an initial sequential injection experiment in which no experimental manipulation was applied to the animal. We made a 12-h test autoradiogram 3 days (ca. $2018 \mathrm{~F}$ half-lives) after FDG injection in order to determine if this effect was due to contamination of the ${ }^{18} \mathrm{~F}$ exposure by ${ }^{14} \mathrm{C}$. The resultant brain images apparent on this autoradiogram indicated that there was indeed a significant ${ }^{14} \mathrm{C}$ contribution to the ${ }^{18} \mathrm{~F}$ image.

In further validation experiments which employed the simultaneous injection procedure, the amounts of $\left[{ }^{14} \mathrm{C}\right] \mathrm{FDG}$ were reduced 5-fold. A test autoradio-

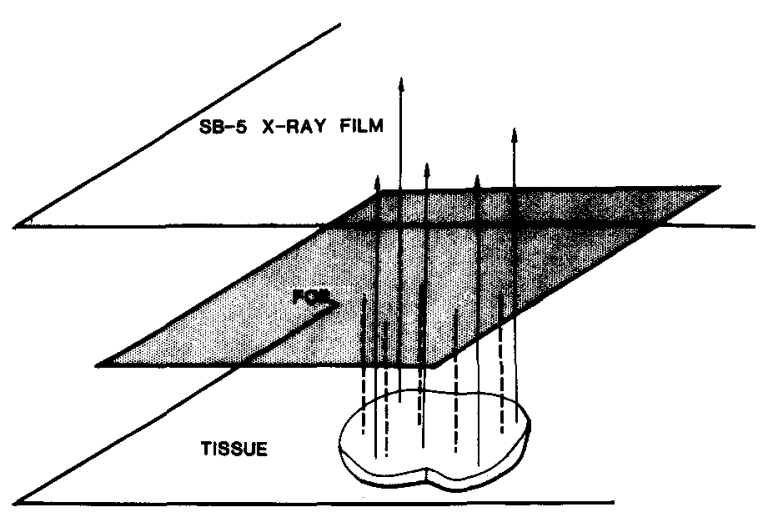

Fig. 2. Diagram illustrating placement of foil screen. The highenergy positrons from ${ }^{18} \mathrm{~F}$ pass through the foil to the film while the low-energy $\beta$-radiation from ${ }^{14} \mathrm{C}$ is filtered out. gram revealed, however, that a significant ${ }^{14} \mathrm{C}$ contribution to the ${ }^{18} \mathrm{~F}$ autoradiogram during the $12-\mathrm{h}$ exposure remained. We therefore next interposed a 50$\mu \mathrm{m}$-thick sheet of aluminum foil between the tissue sections and the $\mathrm{X}$-ray film for the initial exposure (Fig. 2). Densitometry of ${ }^{14} \mathrm{C}$ standards showed that $80 \%$ of the ${ }^{14} \mathrm{C}$ disintegrations were attenuated by the foil. A resultant $26 \%$ attenuation of $18 \mathrm{~F}$ calculated from a tissue standard experiment was used to correct densitometric analyses of ${ }^{18} \mathrm{~F}$ autoradiograms.

A scatter plot (Fig. 3) of the pooled isotope concentrations from two experiments with the foil screen yielded a highly linear best-fit line $(r=0.988)$. The averaged ratios of ${ }^{18} \mathrm{~F} /{ }^{14} \mathrm{C}$ across all the brain regions as determined by spot densitometry was in good agreement with the ratio determined by liquid scintillation and $\gamma$ spectroscopy of brain tissue samples (Table II).

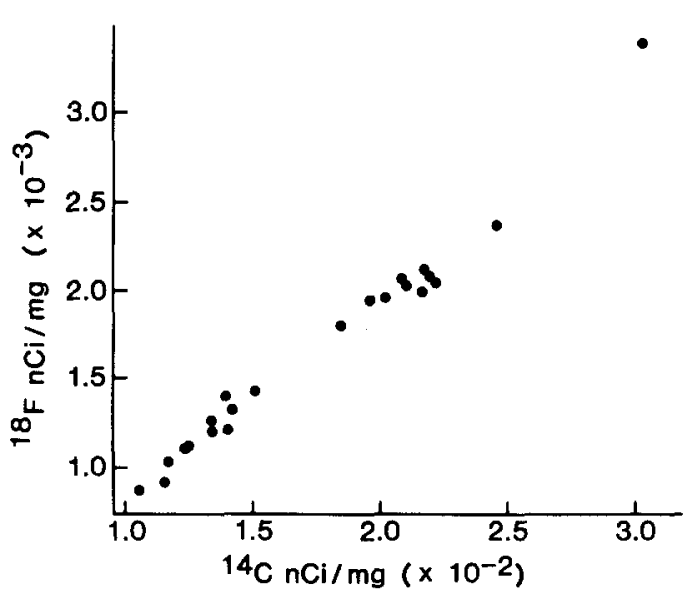

Fig. 3. Scatter plot of pooled isotope concentration data from two rats injected simultaneously with $\left[{ }^{18} \mathrm{~F}\right] \mathrm{FDG}$ and $\left[{ }^{14} \mathrm{C}\right] \mathrm{FDG}$. The isotope ratio for both animals was identical. Correlation coefficient determined by linear regression was 0.988 . 


\section{TABLE II}

Isotope ratios for selected brain regions (pooled data) from two foil validation experiments

Actual isotopic ratio was 91.84 derived from liquid scintillation and $\gamma$ counts of brain tissue. Mean isotopic ratio $=94.26 ;$ S.D. $=6.93$.

\begin{tabular}{lc} 
& Isotopic ratio $\left({ }^{18} \mathrm{~F}^{14} \mathrm{C}\right)$ \\
\hline Striatum & 98.03 \\
Motor cortex & 93.99 \\
Mamillary body & 94.69 \\
Inferior colliculus & 111.66 \\
Periaqueductal gray & 94.57 \\
Medial geniculate & 97.37 \\
Substantia nigra & 91.10 \\
Corticomedial amygdala & 85.10 \\
Hypothalamus & 88.05 \\
Septum & 90.36 \\
Globus pallidus & 91.98 \\
\hline
\end{tabular}

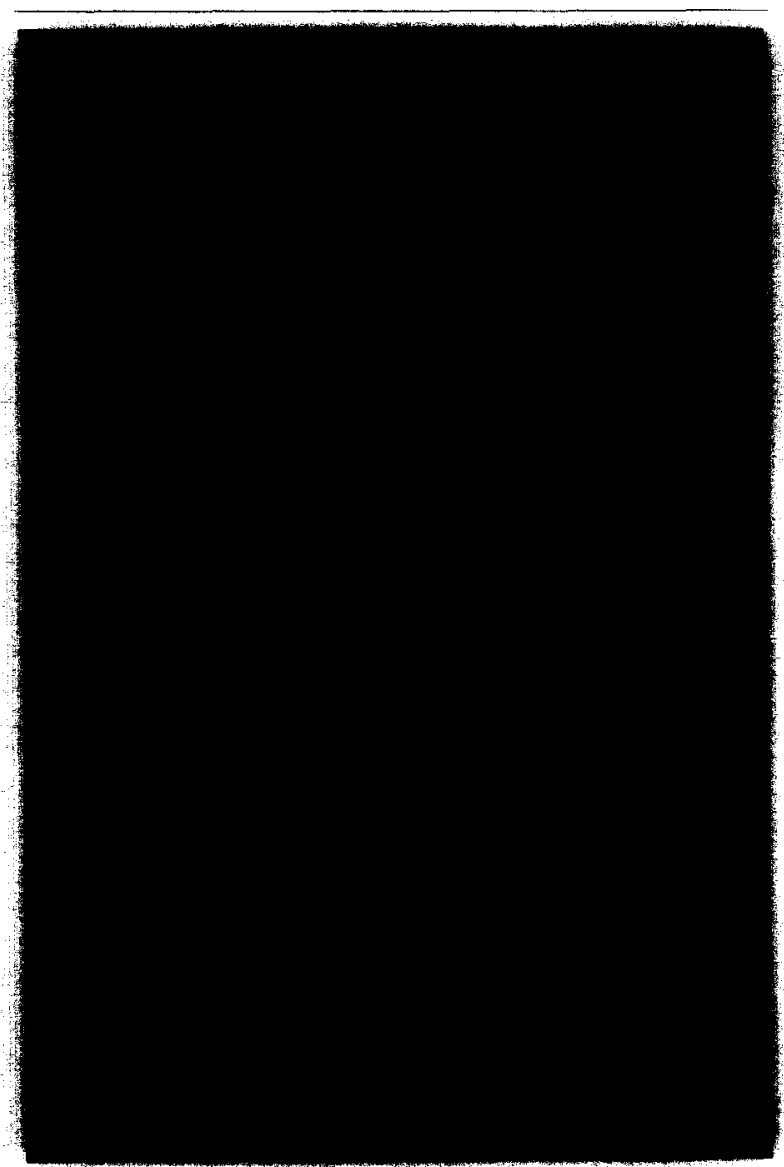

Fig. 4. These computer-digitized autoradiographic images were produced from the same coronal brain section of a rat injected simultaneously with $\left[{ }^{14} \mathrm{C}\right] \mathrm{FDG}$ and $\left[{ }^{18} \mathrm{~F}\right] \mathrm{FDG}$. To reduce the ${ }^{14} \mathrm{C}$ contribution to the ${ }^{18} \mathrm{~F}$ exposure, Reynold's 650 aluminum foil was interposed between the $\mathrm{X}$-ray film and the tissue sections during the first $12 \mathrm{~h}$ of exposure. The foil greatly reduced the ${ }^{14} \mathrm{C}$ contribution to the ${ }^{18} \mathrm{~F}$ image. Upper image: $\left[{ }^{14} \mathrm{C}\right]$ FDG uptake. Lower image: $\left[{ }^{18} \mathrm{~F}\right] \mathrm{FDG}$ uptake.

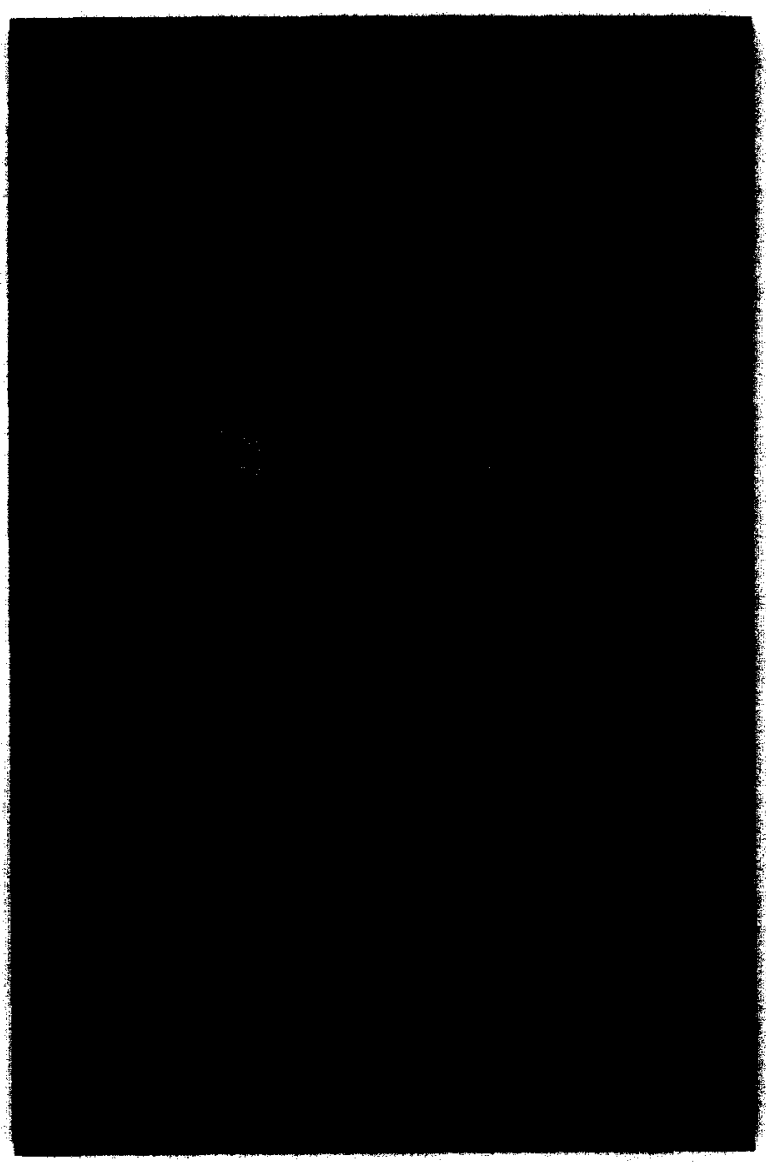

Fig. 5. Computer-digitized autoradiographic images of the same coronal rat brain section 7 days following ibotenic acid lesion of the right striatum using the sequential double-label method. Upper image, control: $\left[{ }^{1+} \mathrm{C}\right] \mathrm{FDG}$ uptake in awake animal. Lower, experimental image: $\left[{ }^{18} F\right] F D G$ uptake in the same animal after pentobarbital injection. Note that lesioned striatum is selectively refractory to the depressing action of anesthesia on brain metabolism.

The autoradiogram pair in Fig. 4 shows how this technique produced two virtually identical FDG incorporation images following simultaneous injection. Autoradiogram pairs for the ibotenic acid lesion experiment are shown in Figs. 5 and 6. As previously demonstrated ${ }^{2}, 11$, the lesioned striatum is selectively insensitive to the depressing effects of barbiturate anesthesia. In addition, the substantia nigra shows a hypermetabolic asymmetry ipsilateral to the lesion in both the awake and anesthetized rat 2.11 . 


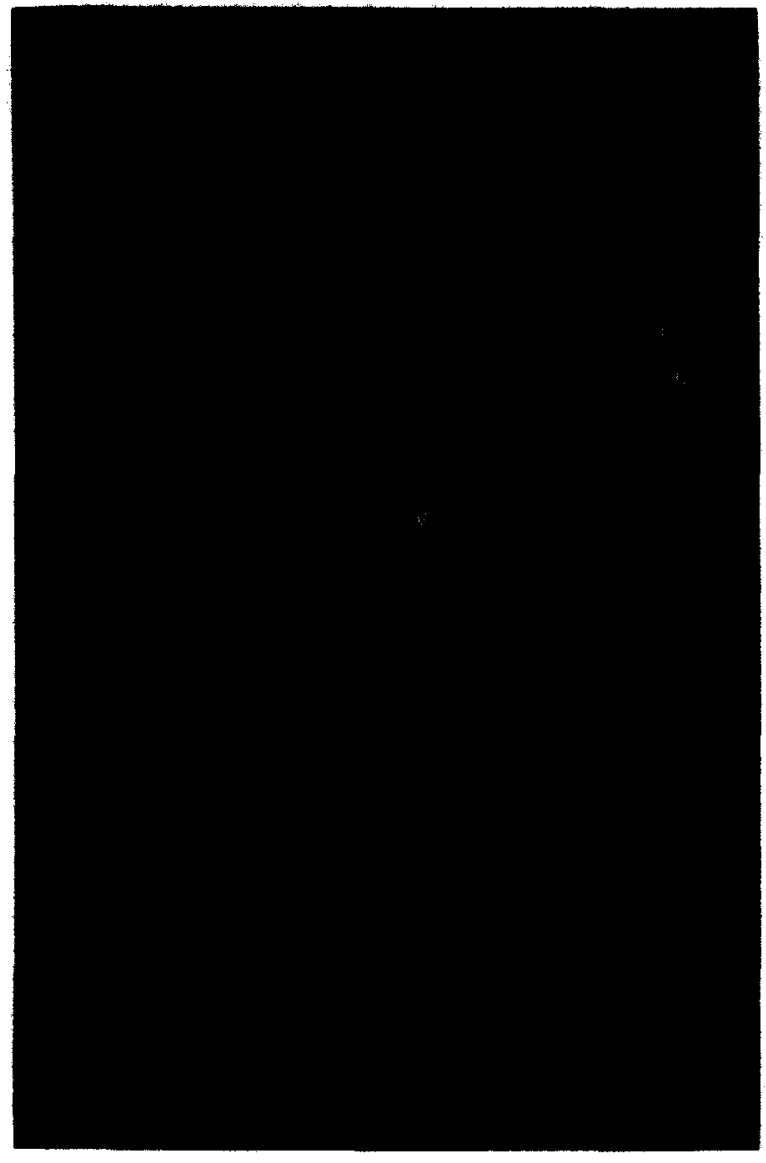

Fig. 6. As Fig. 5 from a more caudal section at the level of the substantia nigra.

\section{DISCUSSION}

The sequential double-label paradigm has been examined previously by means of tissue punches and qualitative 2-DG autoradiography $1,4,17$. It is, however, intrinsic to the punch method that only a limited number of discrete samples can be taken, while the autoradiographic method has the advantage that it simultaneously samples all brain regions at a high level of anatomic resolution. The present autoradiographic sequential double-label method provides control and experimental data pairs for each part of the brain down to the $100-\mu \mathrm{m}$ resolution of the DG method.

The ${ }^{3} \mathrm{H} /{ }^{14} \mathrm{C}$ punch method has previously been used in conjunction with ${ }^{14} \mathrm{C}$ autoradiography ${ }^{1,4}$. In developing the present double-label autoradiographic method, we initially considered using the ${ }^{3} \mathrm{H} /{ }^{14} \mathrm{C}$ combination of isotopes, but were faced with a num- ber of potential obstacles. A major drawback is the low energy of the ${ }^{3} \mathrm{H} \beta$ emission, which leads to profound self-absorption by tissue. Since white matter has a higher percentage of dry weight per unit volume than does gray matter ${ }^{19}$, it is more highly quenched than gray, with the result that densitometric linearity is compromised ${ }^{3}$. A second problem is that of separation of ${ }^{3} \mathrm{H}$ and ${ }^{14} \mathrm{C}$ contributions to autoradiographic exposures. Techniques for distinguishing ${ }^{3} \mathrm{H}$ from ${ }^{14} \mathrm{C}$ in autoradiograms are generally based on two exposures, in the presence and absence of an interposed thin sheet of Mylar or other absorbing material which permits ${ }^{14} \mathrm{C} \beta$ particles, but not the ${ }^{3} \mathrm{H} \beta$ particles, to penetrate the photographic emulsion. Much more ${ }^{3} \mathrm{H}$ than ${ }^{14} \mathrm{C}$ is employed in such experiments, so that the exposure in the absence of an intervening film will be maximally attributable to ${ }^{3} \mathrm{H}$. However, since ${ }^{14} \mathrm{C}$ produces several fold more silver grains than does ${ }^{3} \mathrm{H}$ per disintegration ${ }^{4}, 20-100$-fold more ${ }^{3} \mathrm{H}$ than ${ }^{14} \mathrm{C}$ is desirable. As discussed below, it is possible that these problems can be readdressed and eventually solved.

In the aforementioned ${ }^{14} \mathrm{C} / 18 \mathrm{~F}$ studies ${ }^{26}$, the ratio of $18 \mathrm{~F} / 14 \mathrm{C}$ was about 50 and an initial 2-h autoradiogram exposed within $4 \mathrm{~h}$ of FDG injection produced an image which probably reflected only $18 \mathrm{~F}$ incorporation with little contribution from ${ }^{14} \mathrm{C}$. A second delayed autoradiogram produced 3 days later yielded an autoradiogram that represented only ${ }^{14} \mathrm{C}$ incorporation, which in this case reflected LCBF. Other workers have used $\left[{ }^{18} \mathrm{~F}\right] \mathrm{FDG}$ and $\left[{ }^{14 \mathrm{C}}\right] \mathrm{DG}$ to examine the distribution of chlorpromazine and its effect on glucose metabolism in mice ${ }^{29}$.

Validation of the present ${ }^{14} \mathrm{C} /{ }^{18} \mathrm{~F}$ quantitative autoradiographic method required demonstration that both isotopically labeled forms of FDG were metabolized identically in vivo. Our simultaneous injection experiments, by taking advantage of the fact that both compounds are injected into the animal under conditions which eliminate temporal changes in LCMRglc as a confounding variable, were designed for this purpose. If in fact both compounds were biologically equivalent, the ratio of tracer concentrations (corrected for decay of $18 \mathrm{~F}$ ) should have remained constant throughout the nervous system, reflecting the ratio of the injected radioactive mixture. The isotopic ratios, determined by spot densitometry and based upon calibrated $\left[{ }^{14} \mathrm{C}\right]$ methylacrylate 
standards ${ }^{22}$, were then compared (as an internal control) to ratios derived from counting plasma samples and tissue samples, using both $\gamma$ and liquid scintillation counters. Such an analysis led to the conclusion that the first autoradiogram was contaminated with a contribution from ${ }^{14} \mathrm{C}$. By lowering the amount of injected ${ }^{14} \mathrm{C} 5$-fold, its resultant contribution to a $12-\mathrm{h}$ autoradiogram was reduced. Also, the interposition of a $50-\mu \mathrm{m}$ sheet of aluminum foil attenuated the $18 \mathrm{~F}$ positron radiation to only a moderate extent while blocking most of the ${ }^{14} \mathrm{C} \beta$ particle radiation. The result of these two measures was to vastly improve the autoradiographic separation possible between the two isotopes, so that the 12 -h autoradiogram made with the foil interlayer represented [ $\left.{ }^{18} \mathrm{~F}\right] \mathrm{FDG}$ incorporation with only $1 \%{ }^{14} \mathrm{C}$ contamination. The second autoradiogram, prepared after $>99 \% 18 \mathrm{~F}$ decay, provided the $\left[{ }^{14} \mathrm{C}\right] \mathrm{FDG}$ autoradiographic image.

Our demonstration model for the study of the efficacy of the sequential double-label method has its basis in previous work from this laboratory in which it was shown that brain scar tissue was selectively refractory to the effects of barbiturate anesthesia 2.11 . Seven days after unilateral ibotenate injection into the striatum, it could be shown that glucose utilization was reduced in the region of the injection. If LCMRglc was measured in lesioned animals which had been anesthetized prior to the [ $\left.{ }^{14} \mathrm{C}\right] \mathrm{DG}$ injection, glucose utilization was profoundly reduced in the brain, except in the region of the scar. It was hypothesized that this result might be due to infiltration of the lesion area by inflammatory cells, as is seen in cerebral infarction ${ }^{2}$. This metabolic contrast technique, i.e., with and without barbiturate, served then as a test system of the ${ }^{18} \mathrm{~F} /{ }^{14} \mathrm{C}$ sequential double-label method.

We found two distinct patterns of FDG accumulation for each $20 \mu \mathrm{m}$ tissue slice taken: one pattern represented FDG accumulation in the awake animal and served as a metabolic control, while the second pattern represented FDG accumulation in the anesthetized state.

It appears then, that a quantitative sequential autoradiographic technique for determining LCMRglc is feasible. Its applicability is limited by the local availability of $\left[{ }^{18} \mathrm{~F}\right] \mathrm{FDG}$. Furthermore, the method requires rapid sectioning and film exposure following incorporation. Unlike the longer-lived nu- clides, there is no opportunity for a second exposure if the first one fails. In addition, positrons are inefficient in reducing silver grains, so that relatively large amounts are required. The high-energy $\gamma$ rays produced in the subsequent annihilation reaction do not play a significant role in the film image production, but nevertheless constitute a potential health hazard. The amounts of ${ }^{18} \mathrm{~F}$ radioactivity required $(5 \mathrm{mCi})$ is in the range of radioactivity needed for a human brain scan via PET. Since it was essential to this paradigm that we used identical compounds, we employed $\left[{ }^{14} \mathrm{C}\right] \mathrm{FDG}$ instead of $\left[{ }^{14} \mathrm{C}\right] \mathrm{DG} .\left[{ }^{14} \mathrm{C}\right] \mathrm{FDG}$ is more expensive than $\left[{ }^{14} \mathrm{C}\right] \mathrm{DG}$, but can be used for glucose utilization studies ${ }^{24}$ and has the possible advantage that its brain uptake is superior to that of $\mathrm{DG}^{28}$. A possible confound is introduced, however, in that FDG is asymmetric at the 2-carbon and there is in fact a variable amount of fluorodeoxymannose in FDG preparations 5.25 . This can be problematic, particularly if the percent contamination is different in the ${ }^{14} \mathrm{C}$ and the ${ }^{18} \mathrm{~F}$ preparations, since we assume that both injections are chemically identical. The simultaneous injection experiments indicate that, were fluorodeoxymannose indeed present, the amounts would probably have been similar in both preparations since we observed no change in the isotopic ratio of brain or plasma as a result of in vivo metabolism.

Thus, while these experiments report the successful application of a quantitative method for LCMRglc, they also suggest that the use of another isotopic combination should be pursued. We are at present re-examining the use of ${ }^{3} \mathrm{H}$ with ${ }^{14} \mathrm{C}$ and have to a great extent solved the ${ }^{3} \mathrm{H}$ self-absorption problem by means of lipid extraction ${ }^{21}$. In addition, the problem of the isotope separation in autoradiograms may be amenable to available computer techniques for image analysis.

It is becoming increasingly evident that a sequential double-label technique by use of ${ }^{18} \mathrm{~F} /{ }^{14} \mathrm{C},{ }^{3} \mathrm{H} /{ }^{14} \mathrm{C}$ or some other combination will find applicability 12,20 . Recent use of the DG method in classical conditioning of rats has shown statistically significant learningspecific changes in glucose utilization in the molecular layer of the hippocampus ${ }^{13}$. In addition, specific regional metabolic changes in self-stimulating rats compared with subjects receiving non-contingent stimulation of the same anatomical areas have been 
reported ${ }^{23}$. In all of these instances, a double-label approach should aid the analysis of the relatively small changes in regional cerebral glucose utilization due to the altered state. The technique should also make possible small animal experiments that are applicable to PET, a technique in which within-subject comparisons are made possible by its non-invasive nature.

\section{REFERENCES}

1 Agranoff, B.W., Boast, C.A., Frey, K.A. and Altenau, L.L., Evaluation of regional brain metabolism by a sequential double label 2-deoxyglucose method. In J.V. Passonneau, R.A. Hawkins, W.D. Lust and F.A. Welsh (Eds.), Cerebral Metabolism and Neural Function, Williams and Wilkins, Baltimore, 1980, pp. 331-337.

2 Agranoff, B.W. and Frey, K.A., A regional metabolic contrast method for the study of brain pathology, Ann. Neurol., Suppl. 15 (1984) S93-S97.

3 Alexander, G.M., Schwartzman, R.J., Bell, R.D., Yu, J. and Renthal, A., Quantitative measurement of local cerebral metabolic rate for glucose utilizing tritiated 2-deoxyglucose, Brain Research, 223 (1981) 59-67.

4 Altenau, L.L. and Agranoff, B.W., A sequential doublelabel 2-deoxyglucose method for measuring regional cerebral metabolism, Brain Research, 153 (1978) 375-381.

5 Bida, G.T., Nagichettiar, S. and Barrio, J.R., The synthesis of 2-[F-18]fluoro-2-deoxy-D-glucose using glycals: a reexamination, J. Nucl. Med., 25 (1984) 1327-1334.

6 Coopersmith, R. and Leon, M., Enhanced neural response to familiar olfactory cues, Science, 225 (1984) 849-851.

7 d'Argy, R., Ullberg, S., Stålnacke, C.-G. and Långström, B., Whole-body autoradiography using ${ }^{~}{ }^{1} \mathrm{C}$ with doubletracer applications, Int. J. Appl. Radiat. Isot., 35 (1984) 129-134.

8 Dauth, G.W., Frey, K.A. and Gilman, S., A densitometer for quantitative autoradiography, J. Neurosci. Meth., 9 (1983) 243-251.

9 Ericsson, Y. and Hammarstrom, L., The distribution in the mammal body of $\mathrm{F}^{18}$ and $\mathrm{P}^{32}$ from double-labelled $\mathrm{Na}_{2} \mathrm{PO}_{3} \mathrm{~F}$, Acta Physiol. Scand., 65 (1965) 126-137.

10 Fowler, J.S., MacGregor, R.R., Wolf, A.P., Farrell, A.A., Karlstrom, K.I. and Ruth, T.J., A shielded synthesis system for production of 2-deoxy-2-[18 F]fluoro-D-glucose, J. Nucl. Med., 22 (1981) 376-380.

11 Frey, K.A. and Agranoff, B.W., Barbiturate-enhanced detection of brain lesions by carbon-14-labeled 2-deoxyglucose autoradiography, Science, 219 (1983) 879-881.

12 Friedman, H.R., Bruce, C.J. and Goldman-Rakic, P.S., Double-label 2-DG technique yields double dissociation of functional states with an image differencing method, Soc. Neurosci. Abstr., 10 (1984) 1002.

13 Isseroff, A. and Madar, Y., Effect of previous learning upon uptake of ${ }^{14} \mathrm{C} 2$-deoxyglucose evoked by visual stimulation, Soc. Neurosci. Abstr., 9 (1983) 645.

14 Kempner, E.S. and Miller, J.H., Autoradiographic resolution of doubly labeled compounds, Science, 135 (1962) 1063-1064.

\section{ACKNOWLEDGEMENTS}

We appreciate the expert technical assistance of Jan Patoki and Carla Caretto for synthesis of [18F]FDG. We are also grateful to Charlotte Bay for technical assistance in the deoxyglucose protocols. This work was supported by National Institutes of Health Grant 15655. J.L.O. is a predoctoral trainee under National Institutes of Health Grant T 32 MH14279.

15 Lear, J.L., Jones, S.C., Greenberg, J.H., Fedora, T.J. and Reivich, M., Use of ${ }^{123} \mathrm{I}$ and ${ }^{14} \mathrm{C}$ in a double radionuclide autoradiographic technique for simultaneous measurement of LCBF and LCMRgl. Theory and method, Stroke, 12 (1981) 589-597.

16 Lear, J.L., Ackermann, R., Kameyama, M., Carson, R. and Phelps, M., Multiple-radionuclide autoradiography in evaluation of cerebral function, J. Cereb. Blood Flow Metab., 4 (1984) 264-269.

17 Livingstone, M.S. and Hubel, D.H., Effects of sleep and arousal on the processing of visual information in the cat, Nature (London), 291 (1981) 554-561.

18 Mies, G., Niebuhr, I. and Hossmann, K.-A., Simultaneous measurement of blood flow and glucose metabolism by autoradiographic techniques, Stroke, 12 (1981) 581-588.

19 Norton, W.T., Formation, structure, and bjochemistry of myelin. In G.J. Siegel, R.W. Albers. B.W. Agranoff and R.K. Katzman (Eds.), Basic Neurochemistry, 3rd edn., Little, Brown, Boston, 1981, pp. 63-92.

20 Olds, J.L., Frey, K.A., Ehrenkaufer, R.L., Patoki, J. and Agranoff, B.W., Sequential double label FDG autoradiography of rat brain, Soc. Neurosci. Abstr., 10 (1984) 1002.

21 Olds, J.L., Frey, K.A. and Agranoff, B.W., Autoradiographic approaches to a double-label 2-deoxyglucose method, Trans. Am. Soc. Neurochem., 16 (1985) 148.

22 Pan, H.S., Frey, K.A., Young, A.B. and Penney, J.B., Jr., Changes in $\left[{ }^{3} \mathrm{H}\right]$ muscimol binding in substantia nigra, entopeduncular nucleus, globus pallidus, and thalamus after striatal lesions as demonstrated by quantitative receptor autoradiography, J. Neurosci., 3 (1983) 1189-1198.

23 Porrino, L.J., Esposito, R.U., Seeger, T.. Crane, A.M. and Pert, A., Different patterns of local cerebral glucose utilization: self stimulation vs. experimenter-imposed stimulation to the intracranial ventral tegmental area, Soc. Neurosci. Abstr., 9 (1983) 1171.

24 Reivich, M., Kuhl, D., Wolf, A., Greenberg, J., Phelps, M., Ido, T., Casella, V., Fowler, J., Hoffman, E., Alavi, A., Som, P. and Sokoloff, L., The [ ${ }^{18}$ F] fluorodeoxyglucose method for the measurement of local cerebral glucose utilization in man, Circ. Res., 44 (1979) 127-137.

25 Robinson, G.D., Jr., Phelps, M.E. and Huang, S.C., F-182-deoxy-2-fluoro-D-mannose: biological behavior compared with 2-deoxy-2-fluoro-D-glucose, J. Nucl. Med., 20 (1979) 672.

26 Sako, K., Kato, A., Diksic, M. and Yamamoto, L.Y., Use of short-lived ${ }^{18} \mathrm{~F}$ and long-lived ${ }^{14} \mathrm{C}$ in double tracer autoradiography for simultaneous measurement of LCBF and LCGU, Stroke, 15 (1984) 896-900.

27 Sokoloff, L., Relation between physiological function and energy metabolism in the central nervous system, J. Neuro- 
chem., 29 (1977) 13-26.

28 Sokoloff, L., Reivich, M., Kennedy, C., Des Rosiers, M.H., Patlak, C.S., Pettigrew, K.D., Sakurada, O. and Shinohara, M., The $\left[{ }^{14} \mathrm{C}\right]$ deoxyglucose method for the measurement of local cerebral glucose utilization: theory. procedure, and normal values in the conscious and anesthetized albino rat, J. Neurochem., 28 (1977) 897-916.
29 Som, P., Yonekura, Y., Oster, Z.H., Meyer, M.A., Pelletteri, M.L., Fowler, J.S., MacGregor, R.R., Russell. J.A.G., Wolf, A.P., Fand, I., McNally, W.P. and Brill, A.B., Quantitative autoradiography with radiopharmaceuticals, part 2: applications in radiopharmaceutical research: concise communication. J. Nucl. Med., 24 (1983) 238-244. 